\title{
New Disease Reports \\ First report of severe yellowing outbreaks on tomato in Tunisia associated with Tomato chlorosis virus infection
}

\author{
M. Mnari-Hattab ${ }^{1}$, S. Zammouri ${ }^{1}$, W. Salleh ${ }^{1}$, C. Hdider $^{2}$ and M.R. Hajlaoui ${ }^{1}$ \\ ${ }^{1}$ Laboratoire de Biotechnologie Appliquée à I'Agriculture, INRA Tunisie, Université de Carthage, 2049 Ariana, Tunisie; ${ }^{2}$ \\ Laboratoire d'Horticulture, INRA Tunisie, Université de Carthage, 2049 Ariana, Tunisie
}

*E-mail: hattab.monia@iresa.agrinet.tn

Received: 17 Jun 2014. Published: 20 Jul 2014.

In Tunisia, tomato (Solanum lycopersicum) is the most widely cultivated all year-round vegetable crop. Since 2011 abnormal yellowing symptoms have been observed on field grown tomato crops in Kairouan, a major growing area in Tunisia. These symptoms were uniformly distributed within the fields. However at the end of the growing season it was difficult to distinguish between the yellowing symptoms, and the effects of senescence and other diseases that complicated matters. Initially the yellowing symptoms were confused with physiological and nutritional disorders as has often occurred in many countries.

Monitoring of tomato crops early in the 2014 season revealed severe yellowing on some plants randomly distributed in the field. The symptoms consisted of a uniform light green colouration of affected plants with interveinal chlorosis on individual leaves coalescing into chlorotic mottling on middle-aged leaves. Mature leaves thickened and became brittle and developed intense interveinal chlorosis with some bronzing or brown necrotic flecks by the end of the growing season (Fig. 1). Leaves with such symptoms were often infested with whiteflies thought to be Bemisia tabaci. The intensity, frequency and distribution of the yellowing disorder suggested that virus infection might be responsible particularly as Tomato yellow leaf curl virus (TYLCV), Tomato yellow leaf curl Sardinia virus (TYLCSV) and parental recombinant genus Begomovirus (family Geminiviridae), are widespread in the same tomato growing area (MnariHattab et al., 2014). The symptoms as described are similar to those documented for Tomato infectious chlorosis virus (TICV) and Tomato chlorosis virus (ToCV), both of which are whitefly-transmitted and are members of the Crinivirus genus (Duffus et al., 1996) and have been reported to occur in other Mediterranean countries such as Portugal, Spain, Italy and Morocco (EPPO, 2005).

Following surveys of the tomato crop during 2013 and 2014, leaf samples were collected from both symptom-bearing and symptomless plants and stored at $-80^{\circ} \mathrm{C}$. Total RNA extracted from leaves using CTAB (Salleh et al., 2014) was reverse transcribed and cDNA was amplified by PCR using TICV and ToCV-specific primer pairs as previously described (Louro $e t$ al., 2000; Vaira et al., 2002). Gel electrophoretic analysis of the amplicons revealed that TICV, which has already been documented as an emerging virus in tomato and artichoke in Tunisia (Salleh et al., 2014) was present in
6/20 of symptom-bearing leaf samples. However, $16 / 20$ and 41/44 symptom-bearing samples collected in 2013 and 2014 respectively generated $440 \mathrm{bp}$ amplicons corresponding to that generated by ToCV. No amplicons were produced with extracts from symptomless samples. Four ToCV amplicons were cloned and sequenced. The nucleotide sequences were deposited in GenBank (Accession numbers KJ739306-KJ739309). The nucleotide sequences of the Tunisian isolates shared $99.1 \%$ to $100 \%$ identity and shared more than $99.5 \%$ identity with that of a $\mathrm{ToCV}$ isolate from Italy (Accession No. AM231038). To the best of our knowledge, this is the first report of ToCV in Tunisian tomato crops, which is still considered a quarantine organism in Tunisia. Although we found the virus in a major production region of the country, its distribution is likely to be wider, since the symptoms cannot be distinguished unambiguously from those of mineral deficiency and or physiological disorders.

\section{References}

Duffus JE, Liu HY, Wisler GC, 1996. Tomato infectious chlorosis virus a new clostero-like virus transmitted by Trialeurodes vaporariorum. European Journal of Plant Pathology 102, 219-226.

http://dx.doi.org/10.1007/BF01877960

EPPO, 2005. Data sheets on quarantine pests. Tomato chlorosis virus. Bulletin OEPP/EPPO Bulletin 35, 439-441.

Louro D, Accotto GP, Vaira AM, 2000. Occurrence and diagnosis of tomato chlorosis virus in Portugal. European Journal of Plant Pathology 106, 589-592

Mnari-Hattab M, Zammouri S, Pellegrin F, Gauthier N, 2014. Natural occurrence of Begomovirus recombinants associated with tomato yellow leaf curl disease co-existing with parental viruses in tomato crops and weeds in Tunisia. Journal of Plant Pathology 96, 1-6.

Salleh W, Mnari-Hattab M, Minutillo SA, Spanò R, Zammouri S, Gallitelli D, 2014. First report of tomato infectious chlorosis virus in Tunisia. Journal of Plant Pathology 96, 433.

Vaira AM, Accotto GP, Vecchiati M, Bragaloni M, 2002. Tomato infectious chlorosis virus causes leaf yellowing and reddening of tomato in Italy. Phytoparasitica 30, 290-294. http://dx.doi.org/10.1007/BF03039998

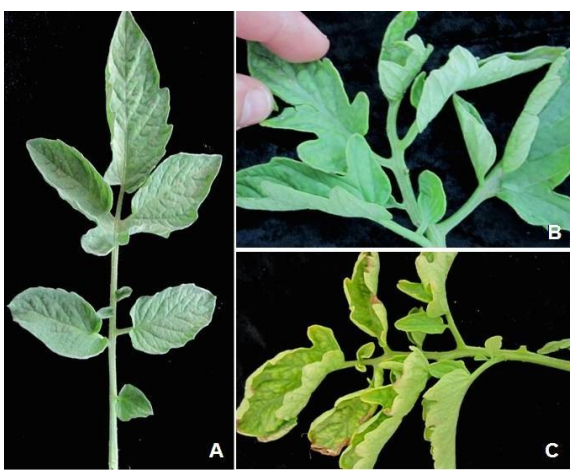

Figure 1

To cite this report: Mnari-Hattab M, Zammouri S, Salleh W, Hdider C, Hajlaoui MR, 2014. First report of severe yellowing outbreaks on tomato in Tunisia associated with Tomato chlorosis virus infection. New Disease Reports 30, 3. http://dx.doi.org/10.5197/j.2044-0588.2014.030.003 